J U R N A L D I S T R I B U S I p-ISSN : 0853-9571

Jurnal Ilmu Manajemen dan Bisnis e-ISSN : 2477-1767

Vol. 7, No. 2 - September 2019

Halaman 141 s.d 154

\title{
ANALISIS PREFERENSI PENGUNJUNG KAWASAN WISATA GILI MENO KABUPATEN LOMBOK UTARA
}

\author{
Emilia Septiani ${ }^{1}$, Budi Santoso ${ }^{2}$, Mulyadi ${ }^{3}$, Muhdin ${ }^{4}$ \\ ${ }^{1}$ Fakultas Ekonomi dan Bisnis Universitas Mataram, Mataram,emiliaseptiani@unram.ac.id \\ ${ }^{2}$ Fakultas Ekonomi dan Bisnis Universitas Mataram, Mataram, hebato@yahoo.com \\ ${ }^{3}$ Fakultas Ekonomi dan Bisnis Universitas Mataram, Mataram, mulyadiunram@gmail.com \\ ${ }^{4}$ Fakultas Ekonomi dan Bisnis Universitas Mataram, Mataram, muhdin@unram.ac.id
}

\begin{abstract}
ABSTRAK
Tujuan dari penelitian ini adalah untuk mengetahui preferensi pengunjung kawasan wisata Gili Meno Kabupaten Lombok Utara. Preferensi pengunjung terbagi ke dalam tiga aspek, yaitu preferensi berdasarkan aspek daya tarik wisata, fasilitas di lokasi wisata, dan aksesibilitas. Metode pengumpulan data yang digunakan dalam penelitian ini adalah sample survey. Teknik pengambilan sampel dalam penelitian ini menggunakan accidental sampling dengan jumlah sampel sebanyak 50 orang responden. Alat analisis yang digunakan dalam penelitian ini menggunakan statistik deskriptif dengan tabel frekuensi.

Hasil penelitian ini menunjukkan bahwa preferensi pengunjung berdasarkan daya tarik wisata adalah keindahan panorama alam dan kegiatan snorkeling; preferensi fasilitas umum yang diperlukan adalah pusat informasi; preferensi tempat menginap adalah homestay; preferensi tempat makan adalah rumah makan atau resturant; preferensi aksesibilitas menuju lokasi wisata adalah kemudahan mencapai lokasi; dan preferensi alat transportasi selama di lokasi wisata adalah sepeda. Untuk aksesibilitas, perlu adanya perbaikan terkait dengan jadwal keberangkatan boat menuju kawasan wisata Gili Meno.
\end{abstract}

Kata Kunci: Preferensi pengunjung, daya tarik wisata, fasilitas, aksesibilitas.

\section{ABSTRACT}

The purpose of this research is to determine visitor preference of tourism area in Gili Meno, North Lombok Regency. As tourist preferences to Gili Meno divided into 3 preferences, i.e. the preference based on tourist attraction, accomodation and accessibility. Data collection method used in this research is sample survey. Sampling technique in this research use accidental sampling with amount of sample counted 50 people. The analytical tools used in this research is descriptive statistics with frequncy tables.

The result of this study showed that: in term of tourist attraction the visitor preferred scenery and for as tourism activity they preferred snorkeling; in term of accomodation they preferred homestay and the place having a meal they preferred restaurant; accessibility preferences towards tourist sites is the ease of reaching the location and in term of transportation they preferred bicycle. Especially for accessibility, improvement the schedule departure of the boat to Gili Meno are needed.

Keywords: Visitor preference, tourist attraction, accomodation, accessibility.

\section{PENDAHULUAN}

\section{Latar Belakang}

Nusa Tenggara Barat (NTB) merupakan salah satu provinsi di Indonesia yang memiliki banyak objek wisata yang potensial. Hal ini dapat dilihat dari jumlah wisatawan, baik wisatawan nusantara maupun wisatawan mancanegara yang datang berkunjung. Berdasarkan informasi dari Badan Pusat Statistik Provinsi Nusa Tenggara Barat (BPS NTB) diketahui bahwa selama kurun waktu 5 tahun terkahir ini mengalami peningkatan yang cukup signifikan. Secara berturut-turut jumlah kunjungan wisatwan ke NTB dari tahun 2013-2107 (khusus 2017 per 29 Desember 2017) adalah 1.357.602 jiwa, 1.629.122 
jiwa, 2.210.257 jiwa, 3.094.437 jiwa dan 3.508.903 (NTB Dalam Angka, 2017). Jumlah kunjungan wisatwan ini pun diprediksi akan semakin bertambah, bahkan Dinas Kebudayaan dan Pariwisata Nusa Tenggara Barat (Disbudpar NTB) manargetkan 4 juta jiwa wisatawan di tahun 2018 (https://ntb.disbudpar.go.id, 2017).

Pulau Lombok merupakan salah satu pulau besar, selain Pulau Sumbawa, yang ada di Provinsi NTB. Pada tahun 2015, Lombok terpilih sebagai pemenang penghargaan World Travel Halal Summit di Abu Dhabi Uni Emirat Arab (https://ntb.disbudpar.go.id, 2016). Kemenangan inilah yang secara tidak langsung membuat terjadinya lonjakan kunjungan wisatawan ke NTB pada umumnya dan Pulau Lombok pada khususnya. Selain itu, saat ini semakin banyak kawasan atau objek wisata yang memiliki kemudahan untuk diakses baik dari segi informasi, transportasi dan akomadasi. Hal ini jelas menjadi pertimbangan tersendiri bagi wissatawan yang ingin bekunjung ke Lombok.

Berdasarkan PERDA Provinsi NTB Nomor 7 Tahun 2013 telah ditetapkannya Kawasan Strategi Pariwisata Daerah (KSPD) Provinsi NTB yang salah satunya terdiri dari dari Destinasi Pariwisata Daerah (DPD) Lombok. Di Pulau Lombok, terdapat 4 KSPD yang meliputi kawasan Mataram Metro, kawasan Senggigi - Tiga Gili, kawasan Kuta - Mandalika, dan kawasan Rasimas - Sembalun. Untuk saat ini, kawasan wisata Senggigi - Tiga Gili masih menjadi primadona bagi wisatawan karena jarak tempuhnya dari pusat kota yang tidak terlalu jauh serta akses transportasi yang sangat memadai dan beragam.

Kawasan Tiga Gili terletak di Kabupaten Lombok Utara yang terdiri dari Gili Trawangan, Gili Meno, dan Gili Air. Untuk Gili Trawangan dan Gili Air, merupakan kawasan yang sudah cukup padat penduduk dan pengunjung sedangkan kawasan Gili Meno masih dapat dikatakan paling recommended untuk mencari ketenangan dan kenyamanan jika dibandingkan dua gili yang lain. Meskipun tergolong lebih sepi dibandingkan wilayah gili yang lain, Gili Meno memiliki potensi wisata yang tidak kalah dengan gili-gili yang lain seperti wisata pantai, wisata bawah laut, wisata olahraga berbasis bahari, dan wisata kuliner. Selain itu, berdasarkan survey pendahuluan yang dilakukan oleh peneliti dengan mewawancarai beberapa wisatawan di wilayah tiga gili menyatakan bahwa Gili Meno masih memiliki keaslian, panorama dan nuansa "private island" yang tidak dimiliki oleh gili-gili yang lain.

Meskipun memiliki keindahan yang dapat dikatakan lebih dari gili yang lain, Gili Meno memiliki keterbatasan. Keterbatasan ini pada umumnya menyangkut fasilitas, terutama fasilitas kesehatan seperti tidak adanya dokter spesialis dan ambulance boat, fasilitas perbankan seperti tidak adanya kantor bank dan fasilitas penjagaan seperti kantor polisi (yang ada hanya pertugas security) Padahal semakin berkembangnya suatu destinasi wisata, maka semakin beragam permintaan wisatawannya terhadap produk wisata (Zanuar dkk., 2017). Wisatawan pun jelas memiliki selera, kebutuhan dan keinginan yang berbeda-beda sehingga berbeda pula produk wisata yang diinginkan.

Keberagaman kebutuhan dan keinginan wisatawan yang berbeda-beda tersebut membuat preferensi konsumen sangat perlu untuk diperhatikan. Preferensi konsumen merupakan sikap suka terhadap satu pilihan produk yang terbentuk melalui evaluasi atas berbagai macam merek dalam berbagai pilihan yang tersedia (Kotler, 2009). Hasil penelitian Pauwah dkk. (2013) menunjukkan bahwa aspek jenis kegiatan wisata, jenis promosi dan informasi, aksesibilitas, dan jenis fasilitas adalah penting menurut preferensi wisatawan; Dwiputra (2013) meneliti mengenai preferensi wistawan terhadap aspek akomodasi, pilihan tempat makan dan pilihan tempat belanja; Rihana dkk. (2014) menunjukkan bahwa atraksi wisata (pemandangan alam, kesenian yang diolah penduduk, budaya desa dan spesies hewan unik) aksesibilitas (kondisi jalan yang baik menuju lokasi 
wisata), fasilitas (penginapan homestay, menginap di rumah warga dan ketersediaan toilet umum), dan organisasi wisata (kebersihan lokasi, pusat informasi wisatwan dan keamanan pengunjung) adalah penting menurut preferensi wisatawan; Zanuar dkk. (2017) menunjukkan bahwa prefernsi penting untuk wisatawan berpasangan adalah aspek transportasi (sepeda), akomodasi (homestay), jenis tempat makan dan minum (restoran), dan aktivitas wisata (snorkeling); Oleh karena itu, preferensi pengunjung destinasi wisata terhadap produk wisata yang meliputi aspek atraksi wisata, fasilitas wisata dan aksesibilitas perlu untuk diteliti sehingga dapat menjadi bahan pertimbangan dan evaluasi bagi para pengelola destinasi dan pelaku pariwisata di wilayah Gili Meno.

\section{Identifikasi Permasalahan}

Kawasan wisata tiga gili yang ada di Kabupaten Lombok Utara merupakan salah satu tujuan wisata yang dikenal oleh banyak orang. Tidak seperti dua gili lain (Gili Trawangan dan Gili Air), kawasan wisata Gili Meno masih dapat dikatakan memiliki keterbatasan produk wisata yang ada di sekitar kawasan dan relatif masih sepi pengunjung.

\section{Tujuan Penelitian}

Berdasarkan uraian pada latar belakang dan identifikasi masalah, maka tujuan dari dilakukannya penelitian ini adalah untuk mengetahui preferensi pengunjung kawasan wisata Gili Meno Kabupaten Lombok Utara dilihat dari aspek atraksi (daya tarik) wisata, fasilitas wisata, dan aksesibilitas.

\section{TINJAUAN LITERATUR}

\section{Preferensi}

Preferensi merupakan bagian dari komponen pembuatan keputusan dari seorang individu (Porteus, 1997). Secara lengkap komponen-komponen tersebut adalah: persepsi, sikap, nilai, kecenderungan. Komponen tersebut saling mempengaruhi seseorang dalam mengambil keputusan. Menurut Subiakto (2009), preferensi berasal dari Bahasa Inggris preference yaitu something prefered, one's first choice, greater liking, giving of priority advantage to something, yang berarti sesuatu yang lebih diminati, suatu pilihan utama, merupakan kebutuhan prioritas dan memberi keuntungan yang lebih baik. Preferensi pelanggan juga dapat diartikan sebagai sikap pelanggan yang menginginkan suatu barang atau jasa berdasarkan kemampuan yang dimiliki untuk memberikan nilai kepuasan terhadap apa yang dibeli atau yang ditawarkan, sehingga orang yang menginginkan barang atau jasa telah mempunyai sikap perilaku pembelian (Asri, 1990).

Mempelajari preferensi pelanggan adalah sangat kompleks, yang dikarenakan banyaknya karakteristik yang mempengaruhi dan kecenderungan untuk saling berinteraksi. Howard dan Sheth mengemukakan preferensi pelanggan dalam suatu gambaran proses pengambilan keputusan membeli. Preferensi pelanggan terdiri atas empat komponen pokok yakni masukan (stimuli), susunan hipotesis (susunan persepsi melalui proses belajar), hasil tanggapan atau keputusan membeli dan karakteristikkarakteristik eksogen (Howard and Seth, 1998). Uraian-uraian tersebut merupakan konsep dan teori yang digunakan sebagai landasan untuk memahami mengenai preferensi pelanggan terhadap pelayanan yang sangat menentukan pengambilan keputusan tersebut secara rasional atau emosional dalam memutuskannya.

Secara gamblang juga dikemukakan oleh Howard dan Sheth (1998) bahwa karakteristik yang paling mendasar mempengaruhi preferensi pelanggan dalam 
pengambilan keputusan secara eksplisit ditentukan oleh lima karakteristik yaitu budaya, sosial, pribadi, ekonomi dan psikologis. Secara rinci disebutkan bahwa karakteristik budaya ditentukan oleh nilai-nilai dasar, sikap, prinsip dan norma-norma yang harus dipahami dalam mementaskan budaya perilaku yang telah tertanam.

Karakteristik sosial ditentukan oleh interaksi dan berbagai perubahan yang terjadi berdasarkan keberadaan keluarga, status sosial dan kelas sosial yang memperlihatkan perbedaan dalam interaksi dan perubahannya. Karakteristik pribadi ditentukan oleh adanya pengaruh usia berupa umur yang memberikan perbedaan pribadi pelanggan antara usia muda dan tua, termasuk pula pekerjaan berpengaruh terhadap implementasi pribadi pelanggan antara yang memiliki pekerjaan dengan yang tidak memiliki pekerjaan, sehingga terlihat adanya perbedaan gaya hidup dari masing-masing pelanggan.

Kondisi ekonomi ditentukan oleh tingkat pendapatan sesuai penerimaan gaji, upah dan insentif yang diterima, hal ini tergantung dari jenis usaha yang ditekuni dan berpengaruh terhadap kondisi tabungan dari masing-masing pelanggan. Karakteristik psikologis, preferensi pelanggan ditentukan oleh motivasi dan persepsi untuk melakukan suatu perilaku. Kelima hal tersebut di atas merupakan karakteristik-karakteristik yang mempengaruhi preferensi pelanggan terhadap pengambilan keputusan pembelian.

Proses pemilihan perjalanan merupakan pemberi warna utama dan pendorong pertama hingga seseorang ingin tahu lebih banyak tentang suatu destinasi. Rasa ingin tahu wisatawan dapat dimunculkan dengan adanya pemasaran. Pengetahuan tentang destinasi akan bertambah berkat pemasaran dan dengan pemasaran pula setiap wisata akan memiliki persepsi. Hasil dari persepsi yang terbentuk adalah preferensi daerah tujuan wisata. Dalam hal ini, setiap wisatawan mempunyai landasan pokok atau prinsip-prinsip yang hendak dipenuhi saat berwisata (Ismayanti, 2010).

\section{Pariwisata}

Pariwisata adalah kegiatan dinamis yang melibatkan banyak manusia serta menghidupkan berbagai bidang usaha (Ismayanti, 2010). Yoeti (2010) yang menjelaskan bahwa pariwisata adalah perjalanan dari suatu tempat ke tempat lain untuk bersenangsenang. Pariwisata juga dikatakan sebagai segala kegiatan dalam masyarakat yang berkaitan dengan wisatawan (Soekadijo, 2000). Menurut Mathieson \& Wall (1982), pariwisata adalah sebuah perjalanan sementara yang dilakukan orang pada suatu tujuan tertentu, dalam jangka pendek, pada tempat yang bukan merupakan tempat yang biasa dikunjunginya (tempat tinggal maupun tempat kerja), dan melakukan kegiatan-kegiatan pada tempat tersebut di mana terdapat beberapa fasilitas yang disediakan untuk memenuhi kebutuhannya, termasuk di dalamnya kunjungan sehari dan darmawisata. Pariwisata sebagai kegiatan yang mencakup orang-orang yang melakukan perjalanan pergi dari rumahnya, dan perusahaan-perusahaan yang melayani mereka dengan cara memperlancar atau mempermudah perjalanan mereka atau membuatnya lebih menyenangkan, dengan maksud melakukan perjalanan tersebut bukan untuk usaha melainkan bersantai (Kusmayadi dan Sugiarto, 2000). Berdasarkan beberapa definisi mengenai pariwisata tersebut dapat ditarik kesimpulan bahwa pariwisata merupakan suatu kegiatan yang dilakukan oleh seseorang ke suatu destinasi wisata yang di dalamnya terdapat fasilitas-fasilitas untuk memenuhi kebutuhannya.

Dalam kegiatan kepariwisataan ada yang disebut subyek wisata yaitu orang-orang yang melakukan perjalanan wisata dan objek wisata yang merupakan tujuan wisatawan. Sebagai dasar untuk mengkaji dan memahami berbagai istilah kepariwisataan, berpedoman pada Bab 1 pasal 1 Undang-Undang Republik Indonesia Nomor 10 Tahun 2009 tentang kepariwisataan yang menjelaskan bahwa: pariwisata adalah berbagai 
macam kegiatan wisata dan didukung berbagai fasilitas serta layanan yang disediakan oleh masyarakat, pengusaha, pemerintah dan pemerintah daerah. Sedangkan kepariwisataan adalah keseluruhan kegiatan yang terkait dengan pariwisata dan bersifat multidimensi serta multidisiplin yang muncul sebagai wujud kebutuhan setiap orang dan negara serta interaksi antara wisatawan dan masyarakat setempat, sesama wisatawan, pemerintah, pemerintah daerah, dan pengusaha.

\section{Preferensi Wisatawan Terhadap Produk Wisata}

Preferensi wisatawan timbul dari keinginan dan kebutuhan wisatawan yang melakukan perjalanan wisata terhadap produk wisata yang ditawarkan. Keinginan dan kebutuhan wisatawan terhadap produk wisata semakin kompleks, dinamis dan menuntut kualitas yang memadai dan dikaitkan dengan prinsip pembangunan berkelanjutan. Konsekuensinya, suatu daerah tujuan wisata harus mampu beradaptasi dalam semua tuntutan perubahan dengan mendengarkan suara dari berbagai pihak yang berkepentingan khususnya wisatawan yang memiliki preferensi yang berbeda dalam memilih obyekobyek wisata yang akan dikunjunginya (Nursusanti dalam Alam, 2010).

Produk wisata berbeda dengan potensi wisata, produk wisata merupakan sesuatu yang sudah siap dikonsumsi oleh wisatawan, sedangkan potensi wisata adalah objek (alam, budaya, dan buatan) yang memerlukan banyak penanganan agar dapat memberikan nilai tinggi dan memiliki daya tarik bagi wisatawan, misalnya pemandangan laut dan pegunungan merupakan potensi yang mempunyai peluang sebagai daya tarik wisata, dan apabila dilengkapi dengan aksesibilitas, infrastruktur dan keramahtamahan yang saling terkait dengan objek-objek tersebut menjadi sebuah produk wisata (Damanik dan Weber, 2006). Semakin lengkapnya dan saling terintegrasi ketiga unsur atraksi, sarana dan prasarana, maka semakin kuat posisi penawaran dalam sistem kepariwisataan. Terkait penelitian objek wisata ditunjukan untuk mengetahui jenis objek wisata, kondisi objektifnya, daya tariknya, sarana dan prasarana pendukungnya, pengelolaannya, peran masyarakat, dunia usaha/ pemerintah setempat dalam pengembangan pariwisata, dampak yang ditimbulkan dan lain-lain. Sedangkan yang terkait dengan kegiatannya, ditujukan dengan mengetahui cara memperkenalkan wisata tersebut kepada wisatawan, motif, tujuan dan yang ingin dicapai pelaku wisata tersebut, dan lain-lain (Wardiyanta, 2006).

Menurut Inskeep (1991) terdapat beberapa aspek dari produk wisata yang umumnya menjadi pertimbangan wisatawan dalam mengnjungi sebuah destinasi objek wisata, yaitu aspek atraksi wisata, fasilitas lokasi wisata dan aksesabiltas. Untuk lebih jelasnya mengenai tiga aspek tersebut akan dijelaskan secara ringkas pada bagian berikut. a. Aspek atraksi (daya tarik) wisata. Atraksi wisata merupakan segala sesuatu yang bersifat melengkapi atau pengisian motif wisata yang diharapkan memenuhi kebutuhan pariwisata (Soekadijo, 1997). Berdasarkan UU No.9 Tahun 1990 tentang Kepariwisataan, atraksi wisata diartikan sebagai "segala perwujudan dan sajian alam dan/ atau kebudayaan, yang secara nyata dapat dikunjungi, disaksikan dan dinikmati wisatawan di DTW". Untuk menjadi atraksi wisata yang baik, dapat memberikan kepuasan dan bisa menahan mereka untuk tinggal lebih lama, ada beberapa syarat yang harus dipenuhi yaitu: Kegiatan dan objek atraksi wisatanya harus dalam keadaan baik; Cara penyajiannya atraksi harus tepat; Harus memenuhi kebutuhan mobilitas spasial yaitu akomodasi, transportasi, dan promosi serta pemasaran; Kondisi dan kesan wisatawan terhadap daya tarik wisata harus dapat menahan mereka selama mungkin. Merujuk penelitian yang dilakukan oleh Yulianto dan Uziadanisah (2008), indikator dari daya tarik wisata ini meliputi faktor pendorong kunjungan (Pendit, 2003) dan jenis pertunjukan yang diminati di lokasi objek wisata (Nursusanti, 2005). 
b. Aspek fasilitas lokasi wisata. Menurut Suharso (2009), fasilitas dibutuhkan untuk melayani wisatawan selama perjalanan dan sebagai pendukung pertumbuhan wisata dan cenderung berkembang saat bersamaan atau sesudah atraksi wisata berkembang. Merujuk penelitian yang dilakukan oleh Yulianto dan Uziadanisah (2008) dan Zanuar dkk. (2017), indikator dari fasilitas lokasi wisata ini adalah pilihan tempat menginap, faktor utama dalam memilih tempat penginapan (akomodasi), pilihan tempat makan dan minum dan faktor utama dalam memilih tempat makan dan minum.

Aspek aksesibilitas. Aksesibilitas ini erat kaitannya dengan sistem linkage. Sistem lingkage merupakan hubungan pergerakan (aktivitas) yang terjadi pada zona makro dan mikro, dengan atau tanpa dilengkapi dengan keberagaman fungsi yang berkaitan dengan aspek fisik, historis, ekonomi, sosial, budaya dan politik. Sistem lingkage disini berupa pedestrian, transportasi dan parkir (Suharso, 2009). Menurut Ishak dan Tanjung (2004) Sistem lingkage terdiri dari Forward linkage yang terkait hubungan diantara lokasi pariwisata dengan lokasi pariwisata lainnya, serta lokasi lain seperti sektor perdagangan, sektor industri, sektor transportasi; dan Backward linkage terkait hubungan diantara sektor didalam lokasi pariwisata tersebut serta hubungan diantara pelaku wisata. Merujuk penelitian yang dilakukan oleh Yulianto dan Uziadanisah (2008) dan Zanuar dkk. (2017), indikator dari aspek asksesabilitas ini adalah penilaian terhadap aksesibilitas dan sarana aksesibilitas (Nursusanti, 2005).

\section{Kerangka Berpikir Penelitian}

Berdasarkan tujuan penelitian dan kajian teori, maka dapat digambarkan kerangka konsep penelitian sebagai berikut:

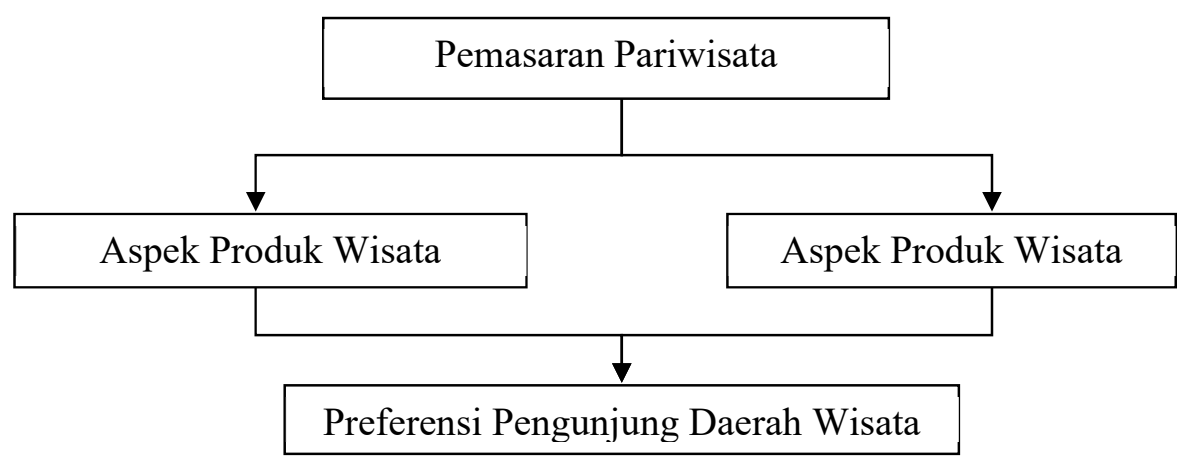

\section{Gambar 3.1. Kerangka Berpikir Penelitian}

Kerangka berpikir penelitian yang ada pada Gambar 1 menunjukkan arah penelitian yang akan dilakukan saat ini. Mengingat perkembangan pariwisata di Pulau Lombok khususnya Kawasan Wisata Gili Meno yang merupakan salah satu primadona dari Tiga Gili, maka penelitian mengenai preferensi pengunjung ini menarik untuk dilakukan atas aspek produk wisata. Setelah mengetahui preferensi pengunjung, pihak pengelola destinasi wisata dan pelaku pariwisata lainnya dapat mengevaluasi dan mempertimbangkan hasil analisis preferensi ini agar dapat meningkatkan kualitas kawasan wisata secara berkesinambungan. 


\section{METODE PENELITIAN}

\section{Metode Pengumpulan Data}

Populasi dalam penelitian ini pengunjung kawasan wisata Gili Meno Kabupaten Lombok Utara yang berusia minimal 18 tahun. Jumlah pengunjung di kawasan wisata ini memiliki jumlah yang tidak diketahui secara pasti karena mengalami fluktuasi sehingga populasi sulit untuk diketahui dengan pasti. Maka dari itu, metode pengumpulan data yang digunakan untk penelitian ini adalah metode sample survey. Metode sample survey merupakan metode pengumpulan data yang dilakukan hanya terhadap sebagian dari anggota populasi (Sugiyono, 2007).

\section{Sampel Penelitian}

Jumlah sampel dalam penelitian ini adalah sebanyak 50 orang responden. Jumlah ini didasari oleh pendapat Roscoe (1975, dalam Sekaran, 2006) yang menyatakan bahawa ukuran sampel lebih dari 30 dan kurang dari 500 adalah tepat untuk kebanyakan penelitian. Untuk memperoleh 50 orang responden ini digunakan teknik non-probability sampling dengan accidental sampling.

\section{Jenis dan Sumber Data}

Jenis data dalam penelitian ini yang kualitatif dan kuantitatif. Untuk data kualitatif ada beberapa data yang akan dikuantitaifkan (seperti: jawaban responden) agar memudahkan peneliti di dalam menginterpretasikan hasil. Sumber data dalam penelitian ini adalah data primer dan data sekunder (jumlah kunjungan wisatawan, harga sewa

sepeda dan harga tiket penyeberangan). Data primer diperoleh dari jawaban responden atas kuesionair yang diberikan.

\section{Variabel Penelitian}

Adapun variabel pada penelitian ini adalah preferensi pengunjung kawasan wisata Gili Meno Kabupaten Lombok Utara terhadap produk wisata yang ditawarkan, meliputi aspek atraksi (daya tarik) wisata, fasilitas lokasi wisata, dan aksesibilitas. Untuk melihat preferensi pengunjung ini responden akan diberikan seperangkat pernyataan tertutup.

\section{Prosedur Analisis Data}

Penelitian ini dianalisis dengan dengan menggunakan statistik deskriptif (descriptive statistics) yang juga disebut statistik deduktif(deductive statistics). Statistik deskriptif merupakan analisis yang paling mendasar untuk menggambarkan keadaan data secara umum. Analisis statistik deskriptif ini dapat berupa tabel frekuensi, eksplorasi data, tabulasi silang dan analisis rasio. Dalam penelitian ini data-data akan disajikan dalam bentuk tabel karakteristik pengunjung dan tabel frekuensi preferensi pengunjung. Tabel preferensi pengunjung akan disusun seperti berikut. 
Tabel 1. Preferensi Pengunjung Kawasan Wisata Gili Meno

\begin{tabular}{|c|c|c|c|c|c|c|}
\hline \multirow{2}{*}{ No Resp. } & \multicolumn{5}{|c|}{ Aspek Produk Wisata } \\
\cline { 2 - 7 } & A & B & C & $\ldots$ & $\ldots$ & Z \\
\hline 1 & & & & & & \\
\hline 2 & & & & & & \\
\hline$\ldots \ldots .$. & & & & & & \\
\hline Dst. & & & & & & \\
\hline N & & & & & & \\
\hline Jumlah & & & & & & \\
\hline
\end{tabular}

Sumber: Zanuar, dkk (2017)

Setelah preferensi masing-masing pengunjung kawasan wisata diketahui, maka akan dilakukan analisis mengenai preferensi pengunjung kawasan wisata terhadap aspek produk wisata.

\section{HASIL PENELITIAN DAN PEMBAHASAN}

Preferensi merupakan keinginan atau minat wisatawan terhadap suatu keadaan yang merupakan cerminan nilai dan sikap kepribadian (personality) dari seseorang yang dapat mengarahkannya kepada proses pencarian bentuk-bentuk kepuasan dan/atau kesenangan yang lebih spesifik (Yulianto dan Uziadansih, 2008). Dalam penelitian ini, analisis preferensi pengunjung kawasan wisata atas produk wisata Gili Meno Kabupaten Lombok Utara (selanjutnya Gili Meno KLU). Menurut UU. No. 10 tahun 2009 tentang Kepariwisataan, sarana pariwisata menyangkut penyediaan akomodasi, makan dan minum, angkutan wisata, sarana wisata tirta, serta kawasan wisata yang dapat dilakukan oleh badan usaha atau perseorangan. Secara umum, produk wisata meliputi tiga aspek utama berupa aspek daya tarik wisata, aspek fasilitas di lokasi wisata, dan aspek aksesabiltas.

Suatu perjalanan rekreasi yang dilakukan oleh seseorang umumnya didasari oleh suatu motif atau alasan sehingga mereka memutuskan untuk melakukan perjalanan tersebut. Oleh karena itu, tujuan perjalanan yang dilakukan oleh seorang wisatawan haruslah menyajikan suatu kondisi yang sesuai dengan alasan atau motifnya. Pengunjung tempat wisata cenderung mempertimbangkan daya tarik wisata yang ada di lokasi tujuan. Daya tarik wisata umumnya menjadi faktor utama yang mampu menarik seorang wisatawan untuk datang. Tabel berikut menunjukkan preferensi pengunjung kawasan wisata Gili Meno berdasarkan aspek daya tarik wisata.

Tabel 2. Preferensi Pengunjung Berdasarkan Aspek Daya Tarik Wisata Tahun 2018

\begin{tabular}{|r|r|r|r|}
\hline \multicolumn{1}{|c|}{ Aspek Daya Tarik Wisata } & Frekuensi & Persentase \\
\hline \multicolumn{2}{|c|}{ a. Daya Tarik Utama } & & \\
\hline 1 & Keindahan panorama alam & 26 & $52 \%$ \\
\hline 2 & Suasana pantai yang nyaman & 24 & $48 \%$ \\
\hline \multicolumn{2}{|c|}{ Jumlah } & $\mathbf{5 0}$ & $\mathbf{1 0 0 \%}$ \\
\hline b. Kegiatan Wisata & 38 & $76 \%$ \\
\hline 1 & Snorkeling & 7 & $14 \%$ \\
\hline 2 & Diving & 5 & $10 \%$ \\
\hline 3 & Lainnya & $\mathbf{5 0}$ & $\mathbf{1 0 0 \%}$ \\
\hline \multicolumn{2}{|r|}{ Jumlah } & & \\
\hline
\end{tabular}

Sumber: Data Primer, 2018 
Pengunjung suatu kawasan wisata cenderung memiliki preferensi tersendiri sehingga memutuskan untuk mengunjungi suatu kawasan wisata. Dari sisi aspek daya tarik wisata, pengunjung kawasan wisata Gili Meno KLU menyukai keindahan panorama alam yang ditampilkan di sekitar lokasi wisata seperti keindahan pantai, panorama bawah laut hingga sunset. Keindahan panorama alam yang disjikan di sekitar kawasan wisata Gili Meno ini membuat para pengunjung menganggap Gili Meno sebagai surga yang tersembunyi. Hal ini karena diantara tiga gili yang ada di kawasan KLU (Gili Air, Gili Trawangan, dan Gili Meno), Gili Meno merupakan kawasan yang relatif masih sepi jika dibandingkan dengam dua gili yang lain. Sejauh ini, sebagian besar wisatawan hanya mengenal Gili Trawangan. Kondisi yang relatif tidak seramai gili lainnya juga menjadi daya tarik utama bagi sebagian pengunjung. Pengunjung dapat merasakan suasana pantai yang nyaman (tidak terlalu ramai dan bising) sehingga akan betah untuk berlama-lama berada di kawasan wisata Gili Meno. Hal ini dapat dilihat dari informasi yang diberikan oleh pengunjung bahwa kedatangan mereka ditujukan untuk menginap. Pengunjung yang datang tetapi tidak sempat menginap merasakan sedikit penyesalan karena tidak dapat mengeksplor kawasan wisata Gili Meno.

Menikmati keindahan alam di kawasan wisata Gili Meno belum lengkap rasanya tanpa menikmati keindahan panorama bawah laut Gili Meno dengan snorkeling ataupun diving. Snorkling menjadi kegiatan favorit para pengunjung kawasan wisata Gili Meno. Dengan melakukan snorkling, para pengunjung dapat melihat karang-karang dan ikanikan yang berwarna-warni tanpa harus menyelam terlalu dalam. Berinteraksi dengan makhluk-makhluk indah tersebut akan menjadi pengalam yang tak terlupakan. Di Gili Meno juga ada disediakan fasilitas diving milik salah satu organisasi yang mendapatkan lisensi diving internasional. Ada beberapa spot indah yang ditawarkan oleh kawasan wisata Gili Meno bagi yang suka menyelam, yaitu Sea Point Penyu, Point Coral Blue, dan Meno Wall.

Perkembangan kegiatan pariwisata di suatu daerah tidak luput dari ketersediaan sarana dan prasarana serta usaha kegiatan pariwisata yang ada. Hal ini mengingat kebutuhan para wisatawan tidak hanya cukup menikmati keindahan ataupun keunikan suatu objek wisata, melainkan juga memerlukan sarana dan prasarana yang dapat berbentuk akomodasi wisata seperti hotel atau penginapan maupun fasilitas pelayanan dasar lainnya seperti rumah makan atau restoran, sumber air bersih, jaringan listrik dan telekomunikasi. Tabel berikut menunjukkan preferensi pengunjung kawasan wisata Gili Meno berdasarkan fasilitas di lokasi wisata.

Tabel 3. Preferensi Pengunjung Berdasarkan Fasilitas di Lokasi Wisata Tahun 2018

\begin{tabular}{|c|c|c|c|}
\hline No. & Aspek Fasilitas di Lokasi Wisata & Frekuensi & Persentase \\
\hline \multicolumn{4}{|c|}{ a. Fasilitas Umum yang Diperlukan } \\
\hline 1 & Toilet umum & 21 & $42 \%$ \\
\hline 2 & Klinik kesehatan & 1 & $2 \%$ \\
\hline 3 & Pusat informasi & 23 & $46 \%$ \\
\hline 4 & Pos keamanan & 3 & $6 \%$ \\
\hline 5 & Tempat pembuangan sampah & 1 & $2 \%$ \\
\hline 6 & Sarana penyewaan & 1 & 0,02 \\
\hline & Jumlah & 50 & $100 \%$ \\
\hline \multicolumn{4}{|c|}{ b. Jenis Tempat Menginap } \\
\hline 1 & Hotel Melati & 2 & $4 \%$ \\
\hline 2 & Homestay & 30 & $60 \%$ \\
\hline
\end{tabular}




\begin{tabular}{|c|c|c|c|}
\hline No. & Aspek Fasilitas di Lokasi Wisata & Frekuensi & Persentase \\
\hline 3 & Hotel berbintang & 2 & $4 \%$ \\
\hline 4 & Villa & 10 & $20 \%$ \\
\hline 5 & Rumah kerabat atau teman & 5 & $10 \%$ \\
\hline 6 & Berkemah & 1 & $2 \%$ \\
\hline & Jumlah & 50 & $100 \%$ \\
\hline \multicolumn{4}{|c|}{ c. Pertimbangan dalam Pemilihan Tempat Menginap } \\
\hline 1 & Harga & 27 & $54 \%$ \\
\hline 2 & Lokasi & 5 & $10 \%$ \\
\hline 3 & Fasilitas yang tersedia & 10 & $20 \%$ \\
\hline 4 & Kebersihan & 2 & $4 \%$ \\
\hline 5 & Keamanan dan kenyamanan & 6 & $12 \%$ \\
\hline & Jumlah & 50 & $100 \%$ \\
\hline \multicolumn{4}{|c|}{ d. Jenis Tempat Makan dan Minum } \\
\hline 1 & Rumah makan atau restaurant & 30 & $60 \%$ \\
\hline 2 & Café & 11 & $22 \%$ \\
\hline 3 & Warung atau kios & 9 & $18 \%$ \\
\hline & Jumlah & 50 & $100 \%$ \\
\hline \multicolumn{4}{|c|}{ e. Pertimbangan dalam Memilih Tempat Makan dan Minum } \\
\hline 1 & Jenis makanan dan minuman & 7 & $14 \%$ \\
\hline 2 & Kualitas makanan dan minuman & 24 & $48 \%$ \\
\hline 3 & Harga & 3 & $6 \%$ \\
\hline 4 & Lokasi & 4 & $8 \%$ \\
\hline 5 & Pelayanan yang baik & 11 & $22 \%$ \\
\hline 6 & Higienitas & 1 & $2 \%$ \\
\hline & Jumlah & 50 & $100 \%$ \\
\hline
\end{tabular}

Sumber: Data Primer, 2018

Dengan melihat aspek daya tarik wisata di kawasan wisata Gili Meno KLU, fasilitas di sekitar kawasan wisata menjadi sangat penting untuk diperhatikan. Keindahan suatu kawasan wisata akan kurang lengkap jika fasilitas akomodasi yang tersedia minim. Untuk fasilitas di sekitar lokasi, kawasan wisata Gili Meno memiliki fasilitas yang cukup memadai dan beragam. Beberapa fasilitas umum yang diperlukan oleh pengunjung kawasan wisata Gili Meno dan menjadi preferensi utama adalah pusat informasi. Pusat informasi diharapkan mampu memberikan petunjuk kepada para pengunjung kawasan wisata Gili Meno terkait dengan lokasi penginapan, petunjuk perjalanan dan hal yang terkait dengan kawasan wisata tersebut.

Selain fasilitas umum, jenis tempat menginap juga menjadi perhatian para pengunjung kawasan wisata Gili Meno KLU mengingat mayoritas pengunjung memilih untuk tinggal beberapa hari. Jenis penginapan yang menjadi preferensi pengunjung di kawasan wisata ini adalah homestay. Sebagian besar pengunjung kawasan wisata ini lebih menyukai menginap di homestay karena pertimbangan harga. Jika dibandingkan dengan harga hotel berbintang atau villa, homestay memiliki harga yang relatif murah tetapi fasilitas yang disediakan cukup baik. Selama menginap di kawasan wisata Gili Meno, pengunjung dapat memilih jenis tempat makan dan minum yang sesuai. Mayoritas pengunjung kawasan wisata Gili Meno menyukai makan dan minum di rumah makan 
atau restaurant dengan jaminan kualitas makanan sebagai pertimbangan utama. Sebenarnya untuk tempat makan dan minum ada pilihan lain seperti café dan warung atau kios.

Selain aspek daya tarik wisata dan fasilitas di lokasi wisata, terdapat satu aspek lagi yang tidak kalah pentingnya yaitu aspek aksesibilitas. Berikut ini disajikan data mengenai preferensi pengunjung kawasan wisata Gili Meno berdasarkan aksesibilitas.

Tabel 4. Preferensi Pengunjung Berdasarkan Aksesibilitas Tahun 2018

\begin{tabular}{|r|l|r|r|}
\hline \multicolumn{1}{|c|}{ No. } & Frekuensi & Persentase \\
\hline \multicolumn{1}{|c|}{ a. Aksesibilitas Menuju Lokasi } & 13 & $26 \%$ \\
\hline 1 & Sarana transportasi & 33 & $66 \%$ \\
\hline 2 & Kemudahan mencapai lokasi & 4 & $8 \%$ \\
\hline 3 & Kondisi jalan menuju lokasi & $\mathbf{5 0}$ & $\mathbf{1 0 0 \%}$ \\
\hline \multicolumn{2}{|c|}{ Jumlah } & 3 & \\
\hline b. Aksesibilitas yang Perlu Ditingkatkan & 38 & $6 \%$ \\
\hline 1 & Jumlah dan jenis moda angkutan & 9 & $76 \%$ \\
\hline 2 & Jadwal keberangkatan & $\mathbf{5 0}$ & $\mathbf{1 0 0 \%}$ \\
\hline 3 & Keamanan dan kenyamanan moda angkutan & & \\
\hline \multicolumn{2}{|r|}{ Jumlah } & 3 & $6 \%$ \\
\hline c. Moda Transportasi & 44 & $88 \%$ \\
\hline 1 & Cidomo & 3 & $6 \%$ \\
\hline 2 & Sepeda & $\mathbf{5 0}$ & $\mathbf{1 0 0 \%}$ \\
\hline 3 & Lainnya & & \\
\hline & Jumlah & & \\
\hline
\end{tabular}

Sumber: Data Primer, 2018

Aksesibilitas menuju pelabuhan penyeberangan menuju Gili Meno tergolong mudah. Bagi pengunjung kawasan wisata Gili Meno yang datang dari luar Pulau Lombok menggunakan pesawat terbang, pengunjung dapat menggunakan jasa angkutan bandara (DAMRI) menuju Senggigi dengan tarif Rp. 40.000 per orang dan waktu tempuh \pm 2 jam perjalanan. Dari Senggigi, pengunjung dapat menuju Pelabuhan Bangsal (public) atau Pelabuhan Teluk Kodeq (private) dengan menggunakan angkutan umum, ojek, ataupun taxi. Setelah tiba di pelabuhan, pengunjung dapat membeli tiket penyeberangan umum atau memilih untuk menyewa kapal. Masing-masing pilihan transportasi dapat dipilih oleh pengunjung dengan menyesuaikan besaran dana yang dimiliki, keamanan dan kenyamanan selama perjalanan, dan waktu tempuh. Misalkan untuk penyebarangan, jika pengunjung memutuskan untuk mebeli tiket peroangan maka pengunjug akan dikenakan tarif sebesar Rp. 12.000,- dari Pelabuhan Bangsal menuju Gili Meno. Hanya saja beberapa pengunjung banyak yang mengeluhkan terkait tidak jelasanya jadwal keberangkatan boat yang akan membawa mereka ke Gili Meno jika membeli tiket perorangan (umum). Berbeda halnya dengan menyewa boat sendiri. Pengunjung harus mengeluarkan nominal uang yang cukup besar sekitar Rp. 250.000,- - Rp. 300.000,- (tergantung kesepakatan), akan tetapi pengunjung dapat langsung berangkat ke Gili Meno.

Setibanya di kawasan wisata Gili Meno, pengunjung dapat memilih moda transportasi yang akan digunakan untuk menyusuri keindahan kawasan wisata gili. Pilihan moda transportasi yang menjadi preferensi pengunjung kawasan wisata Gili Meno ini adalah sepeda. Dua tahun belakangan ini di Gili Meno ada disediakan jasa penyewaan sepeda yang dapat digunakan untuk 
berkeliling oleh pengunjung. Harga sewa yang ditawarkan sekitar Rp. 50.000,-. Dengan mengetahui preferensi pengunjung kawasan wisata Gili Meno terkait produk wisata dengan tiga aspek utama yang ditawarkan, terlihat bahwa pengunjung kawasan wisata Gili Meno cenderung puas dengan aspek wisata utama yang ditawarkan. Pengunjung bahkan menyatakan sendiri bahwa minimnya fasilitas di kawasan wisata Gili Meno (jika dibandingkan dengan Gili Trawangan) justru menjadi daya tarik tersendiri bagi para pengunjung. Pengunjung kawasan wisata jadi dapat menikmati suasana pantai yang private dan bebas dari hiruk pikuk pengunjung.

\section{KESIMPULAN DAN IMPLIKASI}

Berdasarkan hasil penelitian yang telah dilakukan terhadap pengunjung kawasan wisata Gili Meno Kabupaten Lombok Utara terlihat bahwa pengunjung memiliki preferensi terhadap aspek produk wisata yang ditawarkan. Dalam penelitian ini ada tiga aspek yang diamati, yaitu aspek daya tarik wisata, aspek fasilitas di lokasi wisata dan aspek aksesibilitas. Untuk aspek daya tarik wisata, terdiri dari daya tarik utama dan jenis kegiatan wisata. Untuk daya tarik utama, preferensi pengunjung kawasan wisata Gili Meno adalah keindahan dari panorama alam yang ditawarkan oleh Gili Meno. Untuk kegiatan yang dilakukan selama di lokasi wisata Gili Meno, preferensi pengunjung adalah melakukan snorkeling.

Untuk aspek fasilitas di kawasan wisata Gili Meno, fasilitas yang diharapkan dan menjadi preferensi pengunjung adalah ketersediaan pusat informasi. Untuk tempat menginap, preferensi pengunjung adalah homestay dengan harga tempat menginap yang dijadikan sebagai pertimbangan utama. Selain jenis tempat menginap, jenis tempat makan pun menjadi perhatian pengunjung kawasan wisata Gili Meno. Preferensi pengunjung dalam memilih jenis tempat makan adalah rumah makan atau restaurant dengan pertimbangan utama terkait dengan kualitas makanan dan minuman yang disediakan.

Dari sisi aksesibilitas, terutama aksesibilitas menuju lokasi wisata, preferensi dari pengunjung kawasan wisata Gili Meno adalah kemudahan mencapai lokasi wisata. Untuk aksesibilitas yang perlu ditingkatkan adalah jadwal keberangkatan (penyeberangan) dari pelabuhan menuju Gili Meno. Selama melakukan kunjungan wisata di kawasan wisata Gili Meno, pilihan moda transportasi yang menjadi preferensi pengunjung adalah sepeda.

Adapun keterbatasan dari penelitian ini dan arahan untuk penelitian kedepannya adalah sebagai berikut: (1) Jumlah responden yang digunakan dalam penelitian ini sebanyak 50 responden sehingga kedepannya dirasa perlu untuk menambah jumlah responden agar tanggapan atau jawaban responden dapat digeneralisir dengan baik dan lebih representatif; (2) Perlu dipertimbangkannya karakteristik dan/atau pola kunjungan wisata dari aspek social-demografis (3) Penelitian ini hanya berfokus pada preferensi pengunjung kawasan wisata Gili Meno sehingga kedepannya perlu dilihat persepsi pengunjung terhadap atribut produk wisata yang ada di kawasan wisata tersebut; (4) Penelitian kedepan juga perlu melihat bagaimana pengaruh karaketeristik pengunjung dan/atau bauran pemasaran dari produk wisata dalam mempengaruhi keputusan dan/atau kepuasan pengunjung kawasan wisata Gili Meno; dan (5) Pada penelitian ini tidak dipertimbangkan pendapat dari pelaku usaha di kawasan wisata Gili Meno untuk melihat upaya yang telah dilakukan untuk menarik minat kunjungan wisata di kawasan tersebut sehingga untuk penelitian kedepannya perlu menambahkan tanggapan dari pengusaha wisata yang ada di sekitar kawasan wisata Gili Meno. 


\section{REFERENSI}

Alam, W.I. 2010. Identifikasi Persepsi dan Preferensi Pengunjung Tentang Obyek dan Daya Tarik Wisata Situ Bagendit Kabupaten Garut. Bandung: Skripsi Program Studi Perencanaan Wilayah dan Kota Fakultas Teknik dan Ilmu Komputer Universitas Komputer Indonesia.

Badan Pusat Statistik Provinsi Nusa Tenggara Barat. 2017. Provinsi Nusa Tenggara Barat Dalam Angka 2017. Nusa Tenggara Barat: BPS Provinsi Nusa Tenggara Barat.

Damanik, Janianton dan Helmut Weber. 2006. Perencanaan Ekowisata, Dari Teori ke Aplikasi. Yogyakarta: C.V. Andi Offset.

Dinas Pariwisata Provinsi Nusa Tenggara Barat. 2016. Perubahan Lombok Dinobatkan Sestinasi Halal Terbaik Dunia. Rujukan: http://www.disbudpar.ntbprov.go.id/ perubahan-lombok-sejak-dinobatkan-destinasi-halal-terbaik-dunia/ (diakses pada Tanggal 2 Maret 2018).

Dwiputra, Roby. 2013. Preferensi Wisatawan Terhadap Sarana Wisata di Kawasan Wisata Alam Erupsi Merapi, Jurnal Perencanaan Wilayah dan Kota Vol. 24 No. 1 April 2013, p.: 35-48.

Inskeep, Edward. 1991. Tourism Planning and Sustainable Development Approach. New York: Van Nostrand Reinblod.

Ishak dan Hendri Tanjung. 2004. Manajemen Motivasi. Jakarta: P.T. Grasindo.

Ismayanti. 2010. Pengantar Pariwisata. Jakarta: P.T. Grasindo.

Kotler, Philip. 2000. Manajemen Pemasaran di Indonesia (Terjemahan: Ancella Anitawati Hermawan). Jakarta: Salemba Empat.

Kotler, Philip dan Kevin Lane Keller. 2009. Manajemen Pemasaran Edisi 13 Jilid I. Jakarta: Pearson Education.

Jakarta: Pearson Education.

Kusmayadi dan Endar Sugiarto. 2000. Metodologi Penelitian dalam Bidang Kepariwisataan. Jakarta: P.T. Gramedia Pustaka Utama.

Mathieson, A. and Wall G. 1982. Tourism: Economic, Physical and Social Impact. London: Longman.

Nursusanti, Betty K. 2005. Identifikasi Persespsi dan Preferensi Wisatawan Terhadap Objek Wisata dan Daya Tarik Wisata di Kabupaten Cianjur. Bandung: Thesis Institut Teknologi Bandung.

Pauwah, Yusran dkk. 2013. Persepsi dan Preferensi Pengunjung Terhadap Kawasan Wisata Pantai Malalayang, Sabua Vol. 5 No. 1 Mei 2013, p.: 16 - 27.

Pendit, Nyoman S. 1999. Ilmu Pariwisata, Sebuah Pengantar Perdana. Jakarta: Paradnya Paraamita.

Peraturan Daerah Provinsi Nusa Tenggara Barat No.7 Tahun 2013 Mengenai Kawasan Strategis Pariwisata Daerah (KSPD) Provinsi Nusa Tenggara Barat. Rujukan: http://www.disbudpar.ntbprov.go.id/kawasan-strategis/kawasan-strategispariwisata- daerah-kspd/ (diakses pada Tanggal 2 Maret 2018).

Porteus, J.D. 1997. Environment and Berhavior, Planning, and Everyday Urban Life. Boston: Addison - Wesley.

Rihana, Zuhrifa dkk. 2014. Analisis Faktor Pendorong Wisatawan Untuk Mengunjungi Desa Wisata (Studi Kasus Pada Desa Ketingan Sleman Yogyakarta). JOIR Vol. XIII No.2 Juli 2014, p.: $63-74$. 
Schiffman, Leon G. dan Leslie Lazar Kanuk. 2007. Perilaku Konsumen, Terjemahan: Zoelkifli Kasip. Jakarta: P.T. Indeks.

Soekadijo, R.G. 1997. Anatomi Pariwiasata, Memahami Pariwisata sebagai Systematic Linkage. Jakarta: Gramedia Pustaka Utama. 2000. Anatomi Pariwisata, Memahami Pariwisata sebagai System Linkage. Jakarta: P.T. Gramedia Pustaka Utama.

Subiakto. 2009. Preferensi Pengguna dan Penyedia Jasa Terhadap Sistem Jaringan Transportasi Jalan (JTJ) yang Mendukung di Pelabuhan Belitung (Studi Kasus: Pelabuhan Tanjungpandan dan Tanjung Ru). Semarang: Thesis Program Pascasarjana Magister Pembangunan Wilayah dan Kota Universitas Diponegoro.

Suharso. 2009. Perencanaan Objek Wisata dan Kawasan Pariwisata. Malang: PPSUB. Undang - Undang Republik Indonesia No. 10 Tahun 2009 Tentang Kepariwisataan.

Wardiyanta. 2006. Metode Penelitian Pariwisata. Yogyakarta: Andi.

Yoeti, H.O.A. 2010. Dasar - Dasar Pengertian Hospitaliti dan Pariwisata. Bandung: P.T. Alumni Bandung.

Yulianto, Eko dan Idah Uziadanisah. 2008. Identifikasi Persepsi dan Preferensi Wisatawan dan Pengusaha di Kawasan Wisata Terpadu Bojongsari Kabupaten Indramayu. Bandung: Proyek Akhir Jurusan Teknik Planologi Fakultas Teknik Universitas Pasundan.

Zanuar, Zyendira Amanda dkk. 2017. Preferensi Wisatawan Berpasangan Mancanegara Terhadap Produk Wisata di Gili Trawangan Lombok Utara Nusa Tenggara Barat, Jurnal IPTA Vol. 5 No.1, 2017, p.; 45-52. 